\title{
Mužství a ženství v perspektivě feministické antropologie
}

\author{
Václav Soukup \\ Katedra kulturologie Filozofické fakulty Univerzity Karlovy v Praze, Celetná 20, 11000 Praha 1 \\ Do redakce doručeno 7. září 2012; k publikaci přijato 6. listopadu 2012
}

\section{MASCULINITY AND FEMININITY FROM THE PERSPECTIVE OF FEMINISTIC ANTHROPOLOGY}

ABSTRACT The subject of this study is a theoretic analysis of feministic anthropology as a relatively autonomous research approach and an independent anthropological discipline. Special attention will be paid to evolutionary changes of feministic anthropology. The study aims at enhancing the use of gender approach when researching socio-cultural phenomena. That is why feministic anthropology is analysed as an approach which - as opposed to the traditional androcentric study of man - brings into cultural science a "woman's voice" and gender point of view.

KEY WORDS feminism; feministic anthropology; feminity; gender; man; masculinity; woman

ABSTRAKT Předmětem studie je teoretická analýza feministické antropologie jako relativně autonomního výzkumného směru a svébytné antropologické disciplíny. Zvláštní pozornost bude věnována vývojovým proměnám feministické antropologie. Cílem studie je přispět $\mathrm{k}$ aplikaci genderového př́stupu na výzkum sociokulturních jevů. Proto je feministická antropologie analyzovaná jako přístup, který v opozici $\mathrm{k}$ tradičnímu androcentrickému studiu člověka vnáší do vědy o kultuře „ženský hlas“ a genderovou perspektivu.

KLÍČOVÁ SLOVA feminismus; feministická antropologie; feminita; gender; muž; maskulinita; žena

\section{ČLOVĚK SE ŽENOU NERODÍ}

„Produkce feministických významů je nesporným di̊kazem existence více než jedné reality: musí být alespoň dvě!"

Dale Spenderová

Existují dva nadčasové feministické výroky na téma postavení ženy ve společnosti. Autorkou prvního z nich je francouzská spisovatelka a filozofka Simone de Beauvoirová, která shrnula sociokulturní podmíněnost ženských osudů lakonickou větou: „Člověk se ženou nerodí, ale stává“ (Barša 2002, 53). To, že se člověk ženou „stává“, ale bohužel negativně ovlivňuje fakt, že se př́slušnice ženského pohlaví rodí do světa, ve kterém po dlouhá tisíciletí hrají dominantní roli muži. Osudem žen se tak stalo být „druhým pohlavím“, které v patriarchálním světě dominujících mužů zaujímá podřadnou sociální pozici „umlčené skupiny“. Prostředkem nadvlády mužů nad ženami je jak sexualita, tradičně vnímaná jako nástroj „falokratické moci“, tak sociálně sdílené sociokulturní regulati- vy, ideologicky podporující a potvrzující asymetrický vztah mezi mužským a ženským pohlavím. Mužskou nadřazenost ve vztahu k ženám jako maskulinní paradigma moci v oblasti intimního života, výstižně ilustruje druhý slavný feministický výrok, kterým Robin Morganová s jistou nadsázkou komentovala negativní důsledky existence pornografie $\mathrm{v}$ současné společnosti: „Pornografie je teorie, znásilnění praxe“ (Lišková $2004,1)$. Z obou výroků je evidentní snaha poukázat na negativní důsledky života žen $\mathrm{v}$ androcentrické kultuře. Jinými slovy, žena se „stává ženou“ v mužském světě, který ji limituje jako lidskou bytost i jako potenciální umělkyni nebo vědkyni. Pravidla a podmínky pro to, co znamená být „dobrou“ (nebo „špatnou“) ženou, stejně jako vymezení toho co znamená být „dobrý“ (nebo „špatný“) umělec či vědec, vymezili a kodifikovali v západní společnosti muži. Proto $\mathrm{v}$ dějinách lidské kultury existuje nekonečné množství dobrých (nebo špatných) žen, ale pouze omezené množství uznávaných umělkyň, vědkyň nebo držitelek Nobelovy ceny. Jak výstižně konstatovala australská sociolingvistka Dale Spenderová: „Každý obor musí mít nějaké paradigma, model, který pře- 
depisuje, co je a co není předmětem jeho zkoumání, co je relevantní, vhodné a užitečné, ale tato přísně dodržovaná (a dál předávaná) paradigmata jsme nezdědili od nějakého vlídného boha: sestavili je muži“ (Spender 1980, 240). Jednou z razantních reakcí na nerovné příležitosti mužů a žen je feminismus, který v průběhu své existence získal celou řadu podob. Zcela unikátní dimenzi feministickému hnutí ale vtiskla jeho prezentace prostředky vědy. Ve druhé polovině 20 . století se tak setkáváme se snahou učinit „ženský hlas“ a „genderovou perspektivu“ součástí nosných vědeckých paradigmat celé řady společenských věd. Zvláštní místo mezi nimi zaujímá feministická antropologie, která se pokusila odpovědět na otázku „jak se člověk stává ženou“ v transkulturní perspektivě.

\section{FEMINISTICKÁ ANTROPOLOGIE JAKO TYP DISKURZU}

Feministická antropologie se zrodila jako relativně autonomní výzkumný směr v sedmdesátých letech 20 . století jako reakce „rozhněvaných mladých žen“ na tradiční antropologická paradigmata, založená na jednostranně mužské konceptualizaci a interpretaci světa. Feministickou antropologii je možné také vymezit jako antropologickou subdisciplínu, jež se zformovala $\mathrm{v}$ opozici $\mathrm{k}$ androcentricky předpojaté koncepci tradiční sociální a kulturní antropologie. Z tohoto hlediska představuje určitý typ diskurzu - specifickou kulturní konstrukci a prizma, jehož prostřednictvím antropologové, ale především antropoložky interpretují sociokulturní realitu. Feministické antropoložky a antropologové vytvořili řadu explanačních a interpretačních modelů, které nerovnost mužů a žen vysvětlovaly na úrovni kulturních univerzálií nebo specifických lokálních a historických kultur. To, že paradigma feministické antropologie vybudovaly především ženy, umožnilo antropologii vstoupit do období, ve kterém jsou programově přehodnocovány negativní důsledky androcentrické perspektivy, na níž byla tradiční antropologie vybudována. Pravděpodobně právě $\mathrm{v}$ tom spočívá gnozeologická síla feministické antropologie, nebot ve srovnání s tradiční antropologií „vidí lépe“ (z pozice „utlačovaných“) společenské struktury a diskurzivní praktiky, ze kterých nerovnost vyrůstá. Podle britské antropoložky Henrietty L. Mooreové je možné označit za příčinu vzniku a dynamického rozvoje feministické antropologie také skutečnost, že ženy byly přehlíženy jako objekt antropologického výzkumu (Moore 1988). Antropologové totiž měli v průběhu terénních výzkumů tendenci ženy považovat za „němé“, profánní a pasivní objekty manželských transakcí, které uskutečňovali muži - hlavní postavy stojící v centru sociálního života. Podle feministických antropologů a antropoložek se antropologie zrodila jako mužsky dominantní vědní obor. Ženy do antropologie sice vstoupily již na počátku 20. století, ale práci $\mathrm{v}$ terénu zpočátku prováděly podle pokynů a doporučení mužů nebo jako bezplatné pracovní síly. Samotný obor budovali muži, a proto je možné považovat klasickou antropologii za produkt mužské kultury. Tradiční antropologické výzkumy a jejich výstupy byly předpojaté také proto, že antropologové ve svých výzkumech ženám nevěnovali takovou pozornost, jakou si zasloužily. Přestože ženy obvykle tvořily polovinu vzorku populace, s nímž se antropologové $\mathrm{v}$ terénu setkávali, ve svých popisech a interpretacích studované kultury tuto skutečnost ignorovali. Tím, že preferovali jako klíčové informátory muže, de facto přispívali $\mathrm{k}$ umlčování žen. Antropologové jako muži věnovali pozornost především tomu, co ř́kali nebo dělali domorodí muži, nebot’ pouze to považovali za důležité. To mnohdy vedlo $\mathrm{k}$ podcenění nebo ignorování podílu žen na fungování studovaných sociokulturních systémů. Tato situace se radikálně změnila $v$ průběhu šedesátých a sedmdesátých let 20. století, kdy kritika tradiční mužské antropologie přerostla $\mathrm{v}$ etablování feministické antropologie jako relativně autonomní antropologické subdisciplíny, která učinila „svět žen“ relevantní a plnohodnotnou součástí antropologických výzkumů.

Obecně je možné teoretická východiska feministické antropologie shrnout do následujících premis:

1. Tradiční antropologické výzkumy negativně poznamenala absence „ženského hlasu“ a skutečnost, že antropologie vznikla jako produkt mužského světa, který akcentoval androcentrický přístup ke studiu kultur. Proto je nezbytné učinit součástí antropologie kompatibilní „ženskou perspektivu“, založenou na genderovém prrístupu ke studiu sociokulturních jevů.

2. V centru výzkumů feministické antropologie je analýza pohlaví a genderu jako kulturních konstrukcí vzniklých v konkrétním kulturním kontextu.

3. Analýza mužského a ženského světa prostřednictvím pojmu gender umožňuje postihnout variabilitu statusů a rolí žen a mužů v různých kulturách v čase a prostoru.

4. Gender aktivně ovlivňuje a formuje sociokulturní realitu na úrovni jazykové symboliky, kulturních institucí, společenských tříd, sociální struktury i individuálně zažívaných genderových identit.

5. Maskulinitu a feminitu je nezbytné studovat $\mathrm{z}$ genderové perspektivy v širších vztazích a souvislostech v konkrétním historickém, ekonomickém, politickém a mocenském kontextu.

Metody a techniky užívané feministickými antropology a antropoložkami de facto odpovídají standardní antropologické metodologii. Terénní výzkumy, realizované v rámci feministické antropologie, jsou proto většinou založeny na zúčastněném pozorování, rozhovorech, práci s informátory a informátorkami, dotazníkovém šeření, obsahové analýze dokumentů, sběru biografických dat, případových studiích aj. Feministické antropoložky ale neváhaly při svých výzkumech vnášet do studia cizích kultur svoji vlastní genderovou identitu jako nástroj mezikulturního srovnání. Typickou je z tohoto hlediska metoda označovaná jako „engendering knowledge“, která požaduje, aby studium genderových vztahů a ideologií jiných společností probíhalo souběžně s obdobným genderovým výzkumem vlastní kultury. Hlubší porozumění vlastní genderové identitě se tak stává důležitým gnozeologickým nástrojem pochopení genderových identit a vztahů světa „těch druhých“. Velice oblíbenou metodou se staly také autobiografie antropo- 
ložek, které z genderové perspektivy narativně popisují průběh svého terénního výzkumu. Pro tyto terénní monografie je charakteristická snaha antropoložek využít osobní zkušenost k hlubšímu porozumění cizích kultur. Antropologické výzkumy jsou prezentovány jako „narativní dramata“ - barvité a sugestivní príběhy popisující autorčino tápání, rozpaky, bezradnost i zoufalství spjaté s touhou adekvátně popsat a interpretovat zkoumanou kulturu. Tyto texty jsou velice často určeny pro širší čtenářskou obec, což se odráží ve stylu, jímž jsou napsány. Dủležitou součástí feministických terénních výzkumů je využívání etnografického filmu, videa a fotografí, které vizuálně dokumentují a ilustrují průběh a výsledky prací v terénu. V centru výzkumu obvykle stojí gender jako kulturní konstrukt a genderové vztahy, které jsou považovány za významné organizační principy, umožňující porozumět sociální struktuře, distribuci moci, ekonomické a politické nerovnosti a sociokulturní dynamice.

\section{VÝVOJOVÉ PROMĚNY FEMINISTICKÉ ANTROPOLOGIE}

Kořeny feministické antropologie je možné vidět již v období vzniku feminismu. Ten se zrodil jako sociální a politické hnutí bojující za práva žen a jako kritika představ, stereotypů a předsudků o ženě jako o pohlaví, které je považováno za fyzicky i intelektuálně méněcenné.

Paralelně s konstituováním feminismu v západní společnosti pronikaly ideje ženské emancipace také do společenských věd. V kulturní antropologii, stejně jako $\mathrm{v}$ dalších společenských vědách, je toto období označováno jako „první vlna feminismu“ (1850-1920). Tu reprezentují americké antropoložky a etnoložky Alice C. Fletcherová a Elsie C. Parsonsová, které $\mathrm{v}$ opozici $\mathrm{k}$ převládajícímu androcentrickému př́stupu v antropologii anticipovaly „ženskou perspektivu“ a poprvé vnesly do antropologického výzkumu člověka a kultury „ženský hlas“.

Alice Cunningham Fletcherová programově spojila své feministické aktivity $\mathrm{v}$ Association for the Advancement of Women s antropologickými výzkumy kultury indiánského kmene Omahů (Fletcher 1897). Tato antropoložka ale neomezila svi̊j zájem na vědecké studium amerických indiánů, ale pokusila se jim prakticky pomáhat změnit svůj úděl. Podobně jako feministické antropoložky 20. století, i ona viděla podobnost v osudu žen s údělem handicapovaných etnických a minoritních skupin. Fletcherová byla přesvědčena o tom, že jednou z cest k získání „rovných příležitosti'“ je pro americké indiány vzdělání. Proto se angažovala v Carlisle Indian School - vzdělávací instituci, která indiánským dětem v Pensylvánii pomáhala prostřednictvím výuky angličtiny, matematiky a „občanské nauky“ zařadit se do americké společnosti. Alici Cunningham Fletcherovou je možné považovat za první ženu, která se rozhodla stát profesionální antropoložkou. V roce 1890 získala místo v Peabody Museum na Harvardově univerzitě a v roce 1883 jí bylo uděleno členství v American Association for the Advancement of Science. Tento průlom do akademického světa mužů dovršila $\mathrm{v}$ roce 1905 , kdy jako první žena stanula v čele American Folklore Society.

Mezi průkopníky feministické antropologie patří také americká socioložka a antropoložka Elsie Clews Parsonsová, která byla přesvědčena o tom, že je záležitostí osobní volby ženy, zdali bude maskulinní nebo femininní, vášnivá nebo chladná, přizpůsobivá nebo nepřizpůsobivá. Problematiku feministické antropologie originálním způsobem anticipovala ve studii Rodina (1906), ve které prredložila kritiku rodiny jako instituce, která za jistých okolností může přinášet ženám utrpení. Mezi další práce, které měly feministickou dimenzi, patřily zejména studie Náboženská cudnost (1913), Staromódní ženy (1913), Strach a konvence (1914), Společenská svoboda (1915) a Společenská pravidla (1916). Parsonsová patří mezi první ženy, které úspěšně pronikly do světa „mužské antropologie. O vysoké prestiži, kterou Parsonsová získala mezi svými mužskými kolegy, svědčí skutečnost, že stála v čele tak významných institucí, jako je American Folklore Society (1919-1920), American Ethnological Society (1923-1925) a American Anthropological Association (1940).

V letech 1920-1980 se v antropologii prosadila „druhá vlna feminismu“. Její první kumulaci lze zaznamenat po druhé světové válce. Zásadní roli $\mathrm{v}$ tomto období při etablování feministicky orientované antropologie sehrála americká antropoložka Margaret Meadová. Tato mimořádná osobnost světové antropologie již $\mathrm{v}$ průběhu dvacátých a třicátých let 20. století realizovala $\mathrm{v}$ Tichomoří řadu terénních výzkumů, jejichž cílem bylo dokázat, že rozhodující roli při formování mužské a ženské role v průběhu socializace a enkulturace nehraje lidská biologie a genetické faktory, nýbrž kultura a s ní spjaté naučené vzorce chování a prožívání. Své názory shrnula v knize Mužství a ženství: studie pohlaví v měnícím se světě (1949), kterou anticipovala velké téma feministické antropologie - studium vztahu mezi pohlavím jako biologickou kategorií a genderem reprezentujícím uměle vytvořenou kulturní konstrukci (Mead 1949). Meadová svými výzkumy výrazně přispěla $\mathrm{k}$ formulaci hypotézy, že funkce, status, role a vlastnosti, jež lidé v různých společnostech spojují s maskulinitou a feminitou, nevyplývají kauzálním způsobem z biologických rozdílů mezi muži a ženami, ale vznikají jako produkt kulturních předpokladů a praktik, které se proměňují v historickém čase i geografickém prostoru. Ve Spojených státech amerických reprezentovaly „antropologii žen“ druhé vlny feminismu vedle Margaret Meadové zejména Eleanor Leacocková, Lucy Slocumová, Michelle Rosaldová, Louise Lamphereová, Jane Collierová, Gayle Rubinová a Sherry Ortnerová. Ve Velké Británii rozpracovaly v tomto období základy feministické antropologie zejména Shirley Ardnerová, Pat Caplanová a Janet Bujuraová. Všechny tyto antropoložky spojovala snaha o eliminaci jednostranně androcentrického př́stupu ke studiu člověka a kultury a záměr nastolit komplexní genderovou perspektivu.

Novou dimenzi vnesla do feministické antropologie šedesátých a sedmdesátých let 20. století zejména americká kulturní antropoložka Eleanor Burke Leacocková, která pod vlivem historického materialismu, klasického evolucionismu a ne- 
oevolucistické antropologie programově studovala vztah mezi postavením žen a ekonomickou strukturou konkrétní společnosti v historické perspektivě. Podle Leacockové podřízenost žen nepředstavuje kulturní univerzálii, nebot' ve většině tradičních společností ženy neměly nižší postavení než muži. Podřízenost žen a ztráta jejich rovnocenného statusu je údajně důsledkem historického a ekonomického vývoje, který vyústil ve vznik soukromého vlastnictví, nadproduktu, státu, trrídní stratifikace a sociální nerovnosti. Leacocková v této souvislosti vyslovila hypotézu, že v prehistorických sběračských společnostech neexistovaly rozdíly mezi veřejnou a domácí sférou a k podřízení žen dochází až se vzrůstem soukromého vlastnictví. Leacocková se dokonce pokusila prokázat, že ve většině sběračských a loveckých společností existovala před kontaktem se Západem rovnocennost mužů a žen. Proto také ve svých výzkumech věnovala pozornost vlivu koloniální expanze Západu a důsledkům, které mělo šíření kapitalismu na vztahy a postavení mužů a žen v preliterárních společnostech. V centru jejího výzkumného zájmu byla i analýza vztahů mezi pohlavím, sociální rolí mužů a žen, rodinou, výrobním způsobem, třídou a státem. Mezi její nejznámější práce věnované genderové problematice patři například Status ženy v rovnostářské společnosti (1978) nebo Mýtus mužské dominance (1981). Leacocková po celý svůj akademický život čelila kritikám, že jednostranně spojuje problematiku pohlaví a genderu s marxismem, politickou mocí a třídní diskriminací. Svým nekompromisním přístupem, apelujícím na lidskou svobodu a nezávislost přispěla k tomu, že stále více antropologů a antropoložek věnovalo pozornost výzkumu vztahu mužů a žen v konkrétních sociálních, historických, ekonomických a politických kontextech.

Za zásadní průlom $\mathrm{v}$ antropologickém myšlení lze označit skutečnost, že v období druhé vlny feminismu došlo k oddělení pojmů pohlaví a gender. Na uvedení pojmu gender do společenských věd má velkou zásluhu americký psychoanalytik Robert Jesse Stoller, který ve své knize Pohlaví a gender (1968) oddělil biologickou kategorii pohlaví od kulturně konstruované kategorie gender. Podle Stollera je gender pojem, který má psychologické a kulturní konotace, jež mohou být na biologickém pohlaví zcela nezávislé. Zavedení této distinkce znamenalo metodologickou revoluci, která umožnila zásadním zpo̊sobem revidovat epistemologii klasické antropologie a nastolit novou výzkumnou perspektivu. Pojem pohlaví byl i nadále užíván $\mathrm{v}$ tradičním smyslu jako označení biologických rozdílů mezi mužem a ženou, zatímco pojem gender byl vymezen jako analytická kategorie a kulturní konstrukce, která označuje sociokulturní dimenzi maskulinity a feminity. Feminističtí antropologové a antropoložky spjatí $\mathrm{s}$ druhou vlnou feminismu vycházeli $\mathrm{z}$ predpokladu, že gender není kauzálně spojen s biologickým rodem (pohlavím), ale je výsledkem kulturní interpretace těla a sociokulturně konstruované pohlavní identity. Z genderové perspektivy lze feminitu a maskulinitu považovat za výsledek kulturní regulace chování, které je v konkrétní historické nebo lokální kultuře pokládáno za sociálně přiměřené danému pohlaví. Proto jsou ženské a mužské role v různých kulturách odlišné a vari- ují v historickém čase a geografickém prostoru. Gender jako kulturní a současně sémiotická kategorie označuje významy, které daná kultura spojuje s rozdíly mezi mužem a ženou. Nastolení genderové perspektivy umožnilo odhalit nové souvislosti mezi genderem, trrídou, rasou a etnicitou a analyzovat, nakolik je genderová diferenciace provázána s ostatními společenskými mocenskými vztahy.

$\mathrm{Na}$ etablování pojmu gender v kulturní antropologii měla v sedmdesátých letech 20. století velkou zásluhu americká antropoložka Gayle Rubinová, která ve svých pracích originálním způsobem spojila marxistickou politickou ekonomii (Karl Marx), strukturální antropologii (Claude Lévi-Strauss) a psychoanalýzu (Sigmund Freud, Jacques Lacan). Ve svém vlivném eseji Obchodování s ženou: Poznámky $k$ „politické ekonomii" pohlaví (1975) uvedla do antropologie gnozeologický model a výkladové schéma „pohlaví/gender systém“, jímž označila struktury, které $\mathrm{v}$ rámci konkrétní kultury utvárí z „biologické suroviny“ (pohlaví) sociální subjekty (gender). Podle Rubinové prostřednictvím systému „pohlaví/ gender" lidské společnosti transformují biologickou sexualitu do produktů lidské aktivity a poté tyto přeměněné sexuální potřeby uspokojují. Cílem této studie bylo analyzovat sociální mechanismus, který utvárí pohlavní identitu, generuje heterosexualitu jako žádoucí sexuální chování a staví ženy ve společnosti do druhořadé pozice (Rubin 1975). Rubinová svým explanačním modelem „pohlaví/gender" výrazně ovlivnila výzkumy v oblasti genderových studií („gender studies“) a studií zaměřených na gaye a lesby („gay and lesbiens studies"). Feministickou antropologii druhé vlny v sedmdesátých letech 20. století nejvýrazněji reprezentují dva sborníky antropologických článků. První z nich sestavily a publikovaly pod názvem Ženy, kultura a společnost (1974) americké antropoložky Michelle Zimbalist Rosaldová (1944-1981) a Louise Lamphereová (narozena 1941). Jednalo se o soubor esejů a přednášek věnovaných problematice univerzální asymetrie pohlaví a podřízenému postavení žen ve společnosti (Rosaldo - Lamphere 1974). Editorem druhé antologie, která byla vydána pod názvem $K$ antropologii žen (1975), byla Rayna Reiterová (Reiter 1975).

V sedmdesátých letech 20. století se feministická antropologie pokoušela odhalit existenci jednotných, základních principů, jež by dokázaly objasnit podobnosti a rozdíly ve zkušenosti žen. Významným tématem bylo zejména hledání příčin univerzální asymetrie v kulturním hodnocení pohlaví na základě pankulturně rozšířené představy o druhotném postavení žen. K významným reprezentantkám druhé vlny feministické antropologie $\mathrm{z}$ tohoto hlediska patří americká antropoložka Michelle Zimbalist Rosaldová. Ve svých feministických výzkumech Rosaldová věnovala pozornost univerzální transkulturní asymetrii, která existuje $\mathrm{v}$ hodnocení maskulinity a feminity. V centru jejího zájmu stály dvě základní otázky: 1 . Proč jsou muži a jejich aktivity vnímány v různých kulturách jako nadřazené? 2. Proč kulturní systémy podporují mužský svět tím, že přidělují vyšší hodnotu a autoritu mužským rolím a činnostem? Rosaldová si byla vědoma toho, že na genderové asymetrii mají podíl rozdílné biologické faktory, jako jsou 
hormony, sexualita nebo emoce. Za podstatné ale považuje pochopit a popsat, jakým způsobem tyto biologické rozdíly kultura převádí do normativní a ideové roviny a na této úrovni je dále interpretuje. Rosaldová formulovala teorii, podle níž nerovnoměrné rozdělení moci mezi pohlavími a odlišné sociální pozice mužủ a žen ve společnosti souvisí s odlišností soukromé a veřejné sféry. Muži se volně pohybují ve veřejném prostoru a ovládají veřejnou sféru, zatímco ženy jsou připoutány $\mathrm{k}$ domovu a limitovány světem soukromé sféry. Podle Rosaldové tato opozice existuje $\mathrm{v}$ každé společnosti a poskytuje univerzální rámec pro konceptualizaci a interpretaci aktivit mužủ a žen. Rosaldová byla přesvědčená, že ženy jsou převážně identifikovány se soukromým (domácím) životem, zatímco muži se identifikují se životem veřejným. Tento postoj je údajně univerzálně rozšířený ve všech světových kulturách. Protože muži nemají jednoznačně vymezené závazky souvisící s výchovou dětí, mají větší svobodu a prostor $\mathrm{k}$ vytváření sociokulturních norem a sociální struktury společnosti. Muži jsou fyzicky i sociálně oddělení od svých dětí a to jim umožňuje věnovat se politickým a ekonomickým aktivitám. Ve srovnání se ženami, které se cítí být připoutány $\mathrm{k}$ dětem a vytváŕí v rámci soukromé sféry konkrétní svět jistoty, klidu a sounáležitosti, muži jsou ve svých aktivitách motivováni spíše abstraktní autoritou než osobním závazkem. K oddělení soukromé a veřejné sféry přispívá také skutečnost, že muži v mnoha kulturách tráví dlouhý čas na obchodních cestách. V některých kulturách jsou dokonce doma považováni za cizince nebo hosty. K oddělení mužského světa od soukromé sféry přispívají také symbolické rituály. Například na Nové Guineji existují společné mužské domy, ve kterých se odehrávají obřady, jejichž cílem je mladé muže naučit, že jejich sílu, zdraví a krásu negativně poznamená pouto $\mathrm{k}$ domovu. Získaná distanc od rodinné sféry a intimity mužům umožňuje lépe ovládat a kontrolovat sociální prostředí. Oproti tomu ženy mají mnohem menší odstup od lidí, s nimiž jsou v každodenní interakci, a jejich život více prostupuje intimita a důvěrnost než sociální odstup. Navíc jsou více než muži odpovědné za osobní potřeby dětí a lidí ve svém okolí, což jim znemožňuje účinně kontrolovat nebo řídit sociální prostředí. Svưj podíl na utváření pohlavní asymetrie mají také rituály, které v průběhu socializace vymezují status žen a mužủ. Podle Rosaldové se ve většině kultur setkáváme s přesvědčením, že pro mladou dívku je poměrně snadné stát se ženou a že tento proces, ve kterém se dívka stává následovnicí své matky, je jí dán od př́rody. Na rozdíl od mužů jí proto jsou odepřeny rituály potvrzující ženství jako zvláštní kategorii. Symbolický status ženy je spojován se světem př́rody, nebơ je odvozován z biologických a reprodukčních funkcí ženského těla. Ženy jsou také často spojovány $s$ „nečistou“, a proto i „nebezpečnou" dimenzí sociálního života a ztotožňovány s činnostmi, které ohraničují sociální existenci - dávání života, truchlení při pohřbech, krmení dětí, vaření, odklízení odpadu atd. Oproti tomu symbolický status muže je jednoznačně a jasně definován $\mathrm{v}$ termínech jimi vytvořených sociálních institucí. Muži jsou jako tvůrci sociálního řádu a systému lidské zkušenosti spojováni se světem kultury. Ženy díky své biologické a reprodukční funkci stojí na straně př́rody a jsou spojovány s nejednoznačností a nevyzpytatelností (Rosaldo 1974, 31). Opozici mezi soukromou a veřejnou sférou lze identifikovat také na úrovni ekonomické produkce. Antropologické výzkumy sběračských a loveckých společností prokázaly, že ženské ekonomické aktivity jsou více odděleny od veřejného života než aktivity mužské. Ženy obvykle pracují individuálně nebo v malých neorganizovaných skupinách. Produkty jejich práce jsou určeny pro jejich domov a nejbližší okolí. Přestože v tomto typu společností se mohou sběru a lovu účastnit př́slušníci obou pohlaví, sběr je vždy chápán jako výlučně ženská práce. Oproti tomu lov je považován za typicky mužskou aktivitu a obvykle probíhá $\mathrm{v}$ rámci organizované skupiny a úlovek je rozdělen mezi celou komunitu. Pokud ale muž loví individuálně, je jeho úlovek považován za jeho prestižní majetek, který může použít jako součást ceny za nevěstu, dar nebo kompenzaci při rodových sporech (Rosaldo 1974,35). Na základě těchto poznatkủ Rosaldová dospěla k názoru, že ekonomické aktivity žen jsou ve srovnání s muži více individuální a mají konkrétnější podobu.

Podle Rosaldové je možné genderovou asymetrii spjatou s oddělením veřejné a soukromé sféry transkulturně identifikovat na úrovni psychologické, sociální i ekonomické. $\mathrm{K}$ tomu, aby došlo ke změně této situace, vedou podle Rosaldové dvě cesty: vstup žen do veřejného života nebo vstup mužů do soukromé sféry. V souladu s touto hypotézou výzkumy prokázaly, že status žen je nižší ve společnostech, kde jsou striktně odděleny sféry veřejných a soukromých aktivit, ženy výrazně izolovány a umístěny pod autoritativní kontrolu jednoho muže. Oproti tomu nejvíce rovnostářské společnosti jsou ty, ve kterých jsou veřejná a soukromá sféra pouze slabě diferencovány, muži ani ženy neaspirují na autoritu, sociální život je soustředěn kolem domova a ženy mají právo legitimně spolurozhodovat o veřejných věcech.

Osobitý svorník mezi druhou a třetí vlnou feministické antropologie představuje dílo americké kulturní antropoložky Sherry Ortnerové. Ta se podobně jako Michelle Rosaldová pokusila vytvořit explanační model genderové asymetrie založený na hypotéze, že podřízené postavení žen je univerzální, interkulturální fenomén. Diskuse na téma feministická antropologie Ortnerová rozviŕila na počátku sedmdesátých let 20. století zejména svou studií Má se žena $k$ muži jako přiroda ke kultuře? (1974). Na rozdíl od feministických antropologů, kteří zkoumali kulturní rozmanitost mužských a ženských rolí v čase a prostoru, Ortnerová se pokusila odhalit univerzální príčiny ženské podřizenosti ve společnosti. Inspirována knihou Simone de Beauvoirové Druhé pohlaví (1949) a strukturalismem Clauda Lévi-Strausse předložila hypotézu, že vztah muže a ženy odráží dichotomii př́rody a kultury. Podle Ortnerové každá společnost implicitně uznává a prosazuje rozlišování mezi působností přírody a kultury. Kultura oproti př́rodě $\mathrm{v}$ sobě zahrnuje jako základní atributy odlišnost a nadřazenost a disponuje schopností prrírodu transformovat - „socializovat“ a „zkulturňovat“. Ortnerová je přesvědčena, že pankulturně druhořadý status žen je způsobený tím, že muži ,jsou ztotožňováni s kulturou, zatímco ženy jsou ztotož- 
ňovány nebo symbolicky spojovány s přírodou“ (Ortner 1974, 97). Muži, ztotožnění s kulturou, jako nositelé principu transcendence, pak „přirozeně mají tendenci ženy si podřizovat, nebo je dokonce utlačovat. Druhořadost ženy tedy vyplývá z jejího spojování s př́rodou, která je, vzhledem ke kultuře, považována za podřadnou.

Podle Ortnerové lze univerzální podřízenost žen v různých společnostech prokázat prostřednictvím tři klíčových indikátorů: 1. kulturních ideologií a výroků, které explicitně snižují hodnotu žen tím, že jejich rolím, úkolům, produktům a sociálnímu prostředí přisuzují méně prestiže než mužům a mužským aktivitám. 2. symbolických znaků jako např́klad poskvrnění, které jsou interpretovány jako implicitní vyjádření méněcennosti. 3. sociokulturních uspořádání, které ženy vylučuje z činností ve sférách považovaných za sídla nejvyšší moci společnosti nebo jim upírá možnost kontaktu s nimi.

Tyto tři typy údajů mohou i nemusí být $\mathrm{v}$ daném kulturním systému vzájemně propojeny (Ortner 1974: 93). Ortnerová je přesvědčena, že prostřednictvím výše uvedených indikátorů je možné prokázat pankulturní podřízenost žen, která je způsobena tím, že ženy jsou ztotožňovány nebo symbolicky spojovány s př́rodou.

Podle Ortnerové je možné př́činy spojení ženy s přírodou vidět ve fyziologii ženského těla, jež lokalizuje ženu blíže př́rodě a staví ji do sociálních rolí, které jsou považovány za druhořadé. Funkce ženského těla, spjaté s biologickou reprodukcí, a vnucené tradiční sociální role, souvisící s výchovou dětí, strukturují ženskou psychiku, která je pak také chápána jako entita více spjatá s prrírodou. Na sociální úrovni vyrůstá spojování ženy s prŕrodou ze vztahu matky a dítěte a podílu žen na výchově. Vztah mezi kojící matkou a dítětem je chápán jako přirozené biologické pouto. Kojenci většinou nejsou považováni za lidské bytosti, nebot stejně jako zvířata jsou nesocializovaní, neovládají lidskou řeč a kulturní vzorce chování. Proto jsou také považováni spíše za součást př́rody. Spojení žen a kojenců tak i ženě přisuzuje existenci bližší př́rodě nežli kultuře. Na úrovni lidské psychiky Ortnerová identifikovala jako důležitou dimenzi ženského myšlení tendenci zabývat se spíše konkrétními pocity, věcmi a lidmi než abstraktními jevy. Podle Ortnerové tíhnou vztahy žen, stejně jako prŕroda, $\mathrm{k}$ relativní bezprostřednosti a přítomnosti, zatímco muži mají tendenci vytvářet vztahy mnohem zprostředkovanější (Ortner 1974, 108). Tvrzení Ortnerové, že „muž se má k ženě jako kultura k př́rodě“, je rozporuplné. Většina antropologů se shodla na tom, že tento model je př́liš zjednodušující a že rozdíl mezi př́rodou a kulturou nemusí být tak univerzální, jak Ortnerová předpokládá (Eriksen $2008,166)$. Toho si ostatně byla vědoma i sama Ortnerová, která ve svých pozdějších výzkumech přesunula akcent $z$ hledání atributů „univerzální ženy“ $\mathrm{k}$ analýze mužské nadřazenosti v kontextu konkrétních kultur a vztahů mezi sociálními kategoriemi a institucionálními strukturami.

Teorie Sherry Ortnerové, podle níž univerzální mužská dominance nad ženami fatálně souvisí s mužským spojením s kulturou, jejímž úkolem je podmanění a ovládnutí přírody, byla podrobena řadě kritik. Originálním způsobem s touto koncepcí polemizovala např́klad americká antropoložka působící na Pensylvánské univerzitě - Peggy Reeves Sandayová v knize Ženská moc a mužská nadvláda: O počátcích ženské nerovnosti (Sanday 1981).

Podle jejího názoru vztah mužů a žen nelze řešit prostřednictvím dichotomie prŕroda versus kultura, nebot vztah maskulinity a feminity odpovídá spíše základní pojmové symetrii, založené na rozdílech mezi prríslušníky opačných pohlaví. Slovy Sandayové: „Ženy rodí a vychovávají děti; muži zabíjejí a vyrábějí zbraně. Muži předvádějí své úlovky (at je to zvíre, lidská hlava, či skalp) s touž pýchou, s jakou ženy zvedají novorozence. Patř́-li zrození a smrt mezi nevyhnutelné aspekty života, pak muži i ženy přispívají rovným dílem, ale zcela jinými zpo̊soby k pokračování života, a tedy kultury (...) schopnost dávat život je stejně vysoce ceněná jako schopnost jej odnímat" (Sanday 1981, 5-6). Problém ale spočívá v tom, proč některé společnosti hodnotí tyto dvě schopnosti symetricky a jiné asymetricky a jak důsledky preferovaného typu hodnocení ovlivňují světskou moc mužů a žen. Různé alternativy ve scénáríích sexuálních rolí ve studovaných společnostech svědčí o tom, že se jedná o kulturní konstrukty, nikoli o produkty univerzální biologické determinace. Významný podíl na konkrétní podobě jednotlivých scénářo̊ sexuálních rolí mají historické, kulturní a ekologické faktory. Důležité je zejména životní prostředí, $v$ němž se daná společnost nachází a které determinuje způsob, jak si muži a ženy vytváří své genderové identity. Podle Sandayové každé environmentální napětí, at' už je způsobeno nedostatkem potravy, ozbrojenými konflikty, nebo politickou nestabilitou, má tendenci posouvat společnosti směrem $\mathrm{k}$ mužské dominanci a androcentrické mytologii. Oproti tomu, nachází-li se daná společnost v prostředí, které je považováno za bezpečné, dobré a př́íznivé, jsou ženy ze strany mužů považovány za partnery, a nikoli za zdroj nebezpečí pro muže a společnost jako celek.

Třetí vlna feminismu vstoupila do antropologického myšlení v osmdesátých letech 20. století a jako významná součást antropologie dodnes výrazně ovlivňuje teorii i metodologii současných antropologických výzkumů. V centru zájmu feministických antropologů a antropoložek i nadále zůstalo nadčasové téma biologického a kulturního determinismu $\mathrm{v}$ kontextu postmoderní interpretace genderu, etnicity, třídy, rasy nebo socioekonomického statusu jednotlivce. Za výraznou změnu ve strategii feministické antropologie lze označit zejména skutečnost, že antropologové a antropoložky začali zpochybňovat představu univerzální podoby podřízeného postavení žen. Kritice byla vystavena také relevance explanačních modelů maskulinity a feminity založených na binárních opozicích. Charakteristickým rysem třetí vlny feminismu je její sepětí s postmoderní filozofií a tendence kriticky přehodnocovat epistemologické základy předcházejících feministických teorií. Zpochybněno bylo zejména vymezení pojmů pohlaví a gender. Zásadní roli z tohoto hlediska sehrála americká filozofka a feministka Judith Butlerová, působící na Kalifornské univerzitě v Berkeley, která ve svých pracích zpochybnila jak kategorii „ženy“ jako subjektu feminismu, tak distinkci mezi pohlavím a genderem (Butler 1990). Podle jejího názoru 
je možné na pohlaví pohlížet jako na kulturní a normativní konstrukci, která produkuje lidské tělo a prostřednictvím hegemonních diskurzů a heterosexuálních imperativů je poté ovládá. Performativita $\mathrm{z}$ tohoto hlediska představuje řadu praktik, jejichž prostřednictvím je tělo označováno na základě schématu srozumitelnosti a stává se tak známým a snadno pochopitelným kulturním konstruktem. Nonkonformní útok Judith Butlerové na tradiční genderová východiska naznačil, že všechny identity a představy biologicky daného rozdílu mezi mužským a ženským tělem jsou pouhé fikce, které mohou být zpochybněny.

Zjištění, že kategorie genderu nejsou stabilní ani kulturně neměnné, vedlo $\mathrm{k}$ tomu, že v průběhu osmdesátých let došlo ve feministické antropologii $\mathrm{k}$ přesunu zájmu od hledání obecných vysvětlení a teorií k empirickým výzkumům genderu v konkrétním etnickém, trí́dním, rasovém a historickém kontextu. K dekonstrukci kategorie „univerzální ženy“ přispěl také „černý feminismus“, který poukázal na rozdíly mezi zkušenostmi, kulturními reprezentacemi a zájmy černošek a bělošek. Ústřední myšlenkou černého feminismu je tvrzení, že mocenské vztahy mezi černými a bílými ženami byly strukturovány pod vlivem kolonialismu a rasismu. Gender tedy utváří a produkuje různé zkušenosti s tím, co je to „být ženou“ až prostřednictvím toho, jak je konkrétní jedinec začleněn do rasové, etnické nebo národnostní skupiny. Tento př́stup nalezl své vyjádření také v postkoloniální analýze situace žen v jiných než západních společnostech. Například americká postkoloniální literární teoretička indického původu Gayatri Chakravorty Spivaková, působící na Kolumbijské univerzitě v New Yorku, upozorňuje, že západní feminismus, je součástí evropské osvícenské tradice. Proto také jsou některé klíčové koncepty západního feministického myšlení diskriminující a měly by být přehodnoceny. Jak konstatovala ve svém vlivném eseji Mohou marginalizovaní mluvit (1988), dokud feminismus „zůstane nevšímavý ke své vlastní teorii, zůstane ,žena třetího světa jako objekt jeho studia i nadále utvářena hegemonickými intelektuálními praktikami prvního světa“ (Spivak 1988, 81-82). Podle zastánců kritické postkoloniální teorie ne všechny ženy mohou být zařazeny do kategorie „žena“, tak jak ji vymezují západní feministky, a proto „jediné spolehlivé formy vědění o ženách musí být situované, parciální a časově ukotvené“ (Harrington 2006, 331).

Univerzální platnost pojmů, teorií a hodnotících soudů, které jsou spjaty s tradicí západního feminismu, zpochybnila americká antropoložka Lila Abu-Lughodová. Značný ohlas například vyvolala její kritika tvrzení západních feministek, že zahalování muslimských žen je výrazem jejich útlaku, společenské podřízenosti a islámského maskulinního tradicionalismu. Podle Abu-Lughodové není možné hodnotit tyto vzorce chování bez ohledu na individuální pocity muslimských žen, lokální společenské konvence a detailní znalosti způsobu života dané islámské komunity. Antropologické terénní výzkumy Abu-Lughodové, založené na studiu diskurzivních praktik, antropologické reflexivitě a etnografické naraci v konkrétním partikulárním etnografickém kontextu, představují typickou ukázku př́stupů typických pro třetí vlnu feminismu (Abu-Lughod 1986). Pojem kultura již není považován za nezbytný gnozeologický nástroj antropologického výzkumu, nebot údajně uměle odděluje pozorovatele a svět „těch druhých“. Antropologové a antropoložky svoji osobnost považují za součást výzkumu a programově zahrnují domorodou perspektivu do svých výzkumných schémat i interpretací empirických dat.

V současné době představují feministická antropologie a s ní spjaté genderové studie dynamicky se rozvíjející výzkumný proud, který pronikl nejen do antropologického myšlení, ale výrazně ovlivňuje také další společenské vědy včetně sociologie, filozofie, psychologie, historie a archeologie. Tato skutečnost do značné míry souvisí se změnami současné společnosti. Dříve jednoznačně vymezené nezpochybnitelné rozdíly mezi mužskou a ženskou identitou procházejí radikálním přehodnocením. Změny sociálního statusu žen, redefinování tradičních ženských rolí a vztahů mezi muži a ženami, vyžadují nový typ vědecké reflexe respektující existenci dřive umlčované ženské skupiny. Současná feministická antropologie uvádí do vědy stále nové problémové okruhy, redefinuje androcentrické pojmy a reinterpretuje tradiční antropologická témata. Snahou o dekonstrukci jednostranně mužské optiky ve vědě a společnosti a kritikou klasické antropologie tvořivým způsobem otevírá prostor diskusím o postmodernismu, jehož významnou součástí se stále více stává. Slovy australské sociolingvistky Dale Spenderové: „Jestliže ženy začínají pracovat na konstrukci svých vlastních významů, dělají pouze to, na čem muži pracují celá staletí: usilují o pojmenování světa Z vlastní perspektivy“ (Spender 1980, 238).

\section{LITERATURA}

Abu-Lughod, Lila (1986): Veiled Sentiment: Honor and Poetry in a Bedouin Society. Berkeley: University of California Press.

Barša, Pavel (2002): Panství člověka a touha ženy: feminismus mezi psychoanalýzou a poststrukturalismem. Praha: Sociologické nakladatelství.

Beauvoirová, Simone de (1967): Druhé pohlaví. Praha: Orbis.

Bowie, Fiona (2008): Antropologie náboženství. Praha: Portál.

Butler, Judith (1990): Gender Trouble: Feminism and the Subversion of Identity. New York: Routledge.

Eriksen, Thomas Hylland (2008): Sociální a kulturní antropologie. Praha: Portál.

Fletcher, Alice C. (1897): A Study from the Omaha Tribe: The Import of the Totem. American Association for the Advancement of Science, s. 3-12.

Harrington, Austin a kol. (2006): Moderní sociální teorie: základní témata a myšlenkové proudy. Praha: Portál.

Leacock, Eleanor (1978): Women's Status in Egalitarian Society: Implications for Social Evolution. Current Anthropology 19, s. 247-255.

Leacock, Eleanor (1981): Myths of Male Dominance: Collected Articles on Women Cross-Culturally. New York: Monthly Review Press.

Lišková, Kateřina (2004): Pornografie a feministická teorie. Gender, rovné př́ležitosti, výzkum 5, s. 1-4.

Mead, Margaret (1949): Male and Female: A Study of the Sexes in a Changing World. New York: William Morrow \& Co.

Moore, Henrietta L. (1988): Feminism and Anthropology. Cambridge: Polity Press.

Ortner, Sherry B. (1974): Má se žena k muži jako příroda ke kultuře? In Oates-Indruchová, Libora ed. (1998): Dívči válka s ideologií: klasické texty angloamerického feministického myšlení. Praha: Sociologické nakladatelství, s. 91-114.

Reiter, Rayna R. ed. (1975): Toward an Antropology of Women. New York: Monthly Review Press. 
Rosaldo, Michelle Zimbalist (1980): Knowledge and Passion: Ilongot Notions of Self and Social Life. Cambridge: Cambridge University Press.

Rosaldo, Michelle Zimbalist - Lamphere, Louise eds. (1974): Woman, Culture and Society. Stanford: Stanford University Press.

Rubin, Gayle (1975): The Traffic in Women: Notes on the „Political Economy" of Sex. In Reiter, Rayna R. ed. Toward an Antropology of Women. New York: Monthly Review Press, s. 27-62.

Sanday, Peggy R. (1981): Female Power and Male Dominance: On the Origins of Sexual Inequality. Cambridge: Cambridge University Press.

Spender, Dale (1980): Jazyk z dílny mužů. In Oates-Indruchová, Libora ed. (1998): Dívčí válka s ideologii: klasické texty angloamerického feministického myšlení. Praha: Sociologické nakladatelství, s. 238-258

Spivak, Gayatri (1988): Can the Subaltern Speak? In Nelson, Cary Grossberg, Lawrence eds. Marxism and the Interpretation of Culture. London: Macmillan, 271-313.

Stoller, Robert (1968): Sex and Gender: On the Development of Masculinity and Femininity. New York: Science House.
AUTOR

Soukup, Václav, český kulturolog a antropolog, vedoucí Katedry kulturologie na Filozofické fakultě Univerzity Karlovy v Praze, kde přednáší základy sociální a kulturní antropologie, kulturologie a paleoantropologie. Patří k zakladatelům interdisciplinárně koncipovaného studijního oboru kulturologie a průkopníkům biokulturologie. Své názory na předmět, metody a dějiny antropologie shrnul v knihách Dějiny antropologie (2004) nebo Antropologie: teorie člověka a kultury (2011).

Kontakt: PhDr. Václav Soukup, CSc., Katedra kulturologie Filozofické fakulty Univerzity Karlovy v Praze, Celetná 20, 11000 Praha 1, e-mail: Vaclav.Soukup@ff.cuni.cz. 